\title{
Hubungan Gambaran Darah Tepi dan Kadar Presepsin pada Pasien SIRS
}

Meita Hendrianingtyas

\section{Bagian Patologi Klinik, Fakultas Kedokteran, Universitas Diponegoro}

\begin{abstract}
ABSTRAK
Latar belakang : Pasien dengan kondisi sindrom respons inflamasi sistemik (systemic inflammatory response syndromel SIRS) berisiko menjadi sepsis, kegagalan organ dan kematian. Kadar presepsin (sCD14-ST) merupakan salah satu petanda sepsis. Adanya gambaran pergeseran ke kiri, neutrofil teraktivasi (vakuolisasi dan/ atau granulasi toksik) dari gambaran darah tepi dapat menunjukkan suatu keadaan inflamasi/ dan infeksi akut yang mengarah ke sepsis. Tujuan : Membuktikan hubungan antara presepsin dengan keadaan gambaran pergeseran ke kiri, vakuolisasi dan granulasi toksik neutrofil yang didapatkan dari gambaran darah tepi

Metoda penelitian : Penelitian pada 34 pasien yang memenuhi kriteria SIRS di RSUP Dr. Kariadi Semarang. Kadar presepsin diperiksa dengan metoda chemiluminescent enzyme immunoassay (CLEIA), gambaran pergeseran ke kiri dan aktivasi neutrofil (granula toksik dan vakuolisasi) secara mikroskopis ditampilkan dalam positif atau negatif. Uji Gamma and Sommer untuk menganalisis data.

Hasil : Diperoleh nilai hubungan antara kadar presepsin: $\mathrm{r}=0,615 ; p=0,2$ dengan gambaran pergeseran ke kiri; $r=0,696$ dan $p=0,003$ dengan granulasi toksik dan $r$ $=0,775 ; \mathrm{p}=0,001$ dengan vakuolisasi neutrofil
\end{abstract}

Simpulan : Terdapat hubungan positif kuat antara gambaran pergeseran ke kiri, granulasi toksik dan vakuolisasi neutrofil dari gambaran darah tepi

Kata kunci : SIRS, presepsin, pergeseran ke kiri, neutrofil teraktivasi. 


\section{PENDAHULUAN}

Keadaan sepsis merupakan kondisi yang rawan untuk terjadi kegagalan fungsi organ multipel yang akhirnya berakibat pada kematian. Keadaan sepsis secara klinis sulit dibedakan dengan keadaan SIRS. Hal ini menjadi dasar pemikiran bahwa kondisi klinis pasien dengan SIRS bisa berlanjut ke arah yang lebih buruk jika tidak ditangani dengan baik. Penelitian di India tahun 2006 hingga 2009 menunjukkan prevalensi SIRS dengan kegagalan organ sebanyak 25\% dari 1385 kasus SIRS, serta insiden sepsis berat sebanyak $16,45 \%$ dari seluruh kasus. ${ }^{1}$ Penelitian di Eropa menyebutkan bahwa mortalitas pasien dengan infeksi di ICU lebih tinggi dua kali lipat dibandingkan dengan pasien ICU tanpa infeksi.

SIRS merupakan tanda klinik pasien dengan respon inflamasi secara sistemik dengan berbagai penyebab mendasar. The American College of Chest Physicians and the American Society of Critical Care Medicine (ACCP/SCCM) Consensus Conference Committee (1991) menyatakan definisi dari SIRS yaitu adanya dua atau lebih dari empat kriteria berikut ini, temperatur $>38 \square \mathrm{C}$ atau $<36 \square$ C; takikardi $>90 \mathrm{kali} /$ menit; laju pernafasan $>20 \mathrm{kali} /$ menit atau $\mathrm{PaCO} 2<4,3 \mathrm{kPa}(32 \mathrm{mmHg})$; jumlah leukosit $>12.000 / \mathrm{mm}^{3}$ atau $<4000 / \mathrm{mm}^{3}$ atau $>10 \%$ neutrofil bentuk imatur.

Berbagai petanda telah diteliti dan dapat memprediksi keadaan sepsis, salah satunya adalah presepsin. Presepsin adalah fragmen terminal dari CD14 (cluster-of-differentiation) yang merupakan reseptor permukaan sel untuk mengikat lipopolisakarida (lipopolysaccharide/ LPS) atau LPS yang terikat oleh LPS binding protein/ LBP (dikenal dengan LPS-LBP complex / kompleks LPSLBP). CD14 berperan dalam transduksi intraseluler terhadap sinyal endotoksin bakteri gram negatif, serta dapat berikatan dan bereaksi dengan ligand bakteri lain (lipotheoic acid/ LTA dan peptidoglycan/PGN). Fraksi soluble dari CD14 (sCD14) akan diproduksi berkaitan dengan adanya bagian dari bakteri. Fraksi sub type dari sCD14 (sCD14-ST) inilah yang selanjutnya diketahui dengan nama presepsin.

Pemeriksaan gambaran darah tepi merupakan pemeriksaan murah, mudah dan sederhana yang dapat memprediksi adanya infeksibakteri. Keadaan pergeseran ke kiri dimana terdapat peningkatan sel neutrofil imatur dari hasil hitung jenis leukosit, adanya granulasi toksik dan vakuolisasi pada neutrofil dapat mendukung adanya infeksi bakteri pada pasien sebagai awal penentuan 
kecenderungan ke arah sepsis. Keadaan ini juga menunjukkan adanya inflamasi akut. ${ }^{10,11}$

Penelitian ini ingin menganalisis lebih lanjut mengenai hubungan gambaran darah tepi, yaitu gambaran pergeseran ke kiri, granulasi toksik dan vakuolisasi neutrofil pada pasien SIRS.

\section{METODE}

Penelitian ini adalah penelitian deskriptif analitik dengan pendekatan belah lintang yang dilakukan pada RSUP Dr.Kariadi Semarang. Pemeriksaan spesimen dilakukan di Instalasi Laboratorium RSUP Dr.Kariadi Semarang. Populasi target adalah pasien dewasa di ICU dan ruang rawat inap RSUP Dr.Kariadi Semarang. Populasi terjangkau adalah pasien dewasa dengan diagnosis SIRS di ICU dan ruang rawat inap RSUP Dr.Kariadi Semarang. Pemilihan subyek secar consecutive sampling diamna subyek dipilih secara non random berdasarkan kriteria inklusi dan eksklusi penelitian hingga sampel terpenuhi. Kriteria inklusi adalah pasien dengan usia lebih dari 14 tahun dan memenuhi 2 atau lebih kriteria SIRS menurut ACCP/SCCM.

Kriteria eksklusi dari penelitian ini adalah kelainan hematologi dan penyakit autoimun. Data dikumpulkan dari catatan medik, anamnesis, pemeriksaan fisik dan pemeriksaan laboratorik. Kadar presepsin serum yang diukur dengan metode chemiluminescent enzyme immunoassay (CLEIA) pada alat autoanalyzer dengan satuan pg/mL. Kadar presepsin dibedakan menjadi tiga kelompok yaitu $>1000 \mathrm{pg} / \mathrm{mL} ; 600-1000 \mathrm{pg} / \mathrm{mL}$ dan $<600 \mathrm{pg} / \mathrm{mL}$. Pembagian kelompok ini berdasarkan dari referensi yang ada.

Gambaran pergeseran ke kiri dari hitung jenis leukosit yang ditunjukkan dengan peningkatan jumlah neutrofil batang, dan/atau ditemukannya metamielosit dan/ mielosit neutrofil pada preparat apus darah tepi secara manual mikroskopis. Hasil dinyatakan dalam positif atau negatif. Granulasi toksik dan vakuolisasi pada neutrofil dilihat dari preparat apus darah tepi yang dibaca secara manual mikroskopis, dinyatakan sebagai positif atau negatif. Hasil pemeriksaan mikrosopis dilakukan oleh dua orang pemeriksa dan telah dilakukan uji hubungan dengan hasil positif kuat $(\mathrm{r}=0,78 ; p=0,00)$

\section{HASIL PENELITIAN}

Subyek penelitian sebanyak 34 pasien dengan rerata usia 52,7 $\pm 17,6$ tahun, dengan usia paling muda adalah 16 tahun dan tertua adlah 89 tahun. Sebanyak 6 $(17,6 \%)$ orang pasien dirawat di ruang rawat inap sedangkan sisanya sebanyak 28 
$(82,4 \%)$ dirawat di ruang rawat intensif. Data kadar presepsin dapat dilihat pada gambar 1.

\section{Data Kadar Presepsin}
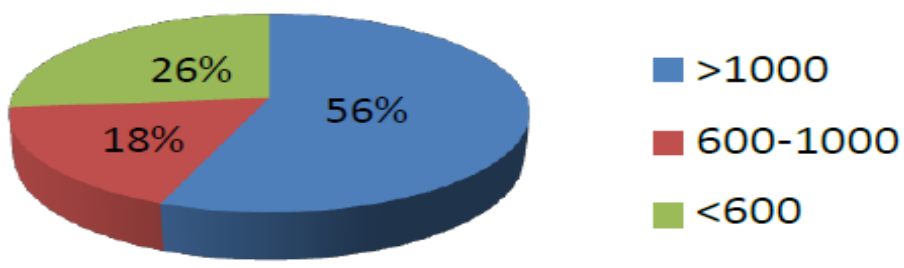

Gambar 1. Data Kadar Presepsin

Kadar presepsin terendah adalah $286 \mathrm{pg} / \mathrm{mL}$ dan kadar tertinggi adalah $15687 \mathrm{pg} / \mathrm{mL}$ pada 34 subyek. Sebanyak 19 (56\%) dengan kadar diatas 1000 pg/mL; sebanyak 9 (26\%) dengan kadar antara 600-1000 pg/mL dan 6 (18\%) dengan kadar $<600$ pg/mL.

Gambar 2, 3 dan 4 berikut ini menunjukkan data gambaran pergeseran ke kiri, vakuolisasi dan toksik granulasi neutrofil.
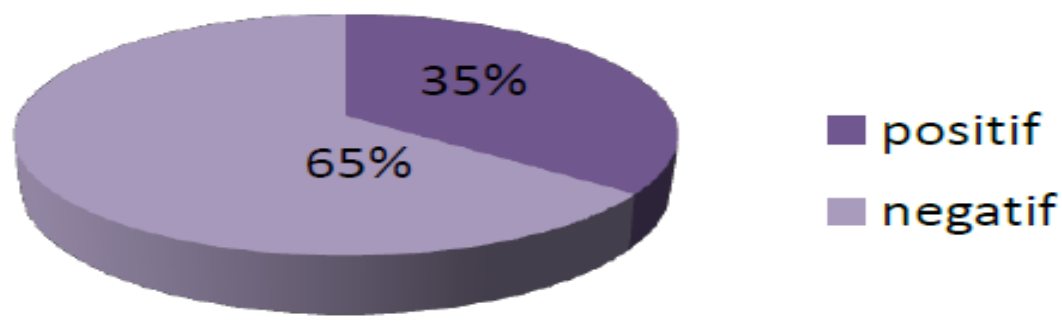

Gambar 2. Data gambaran pergeseran ke kiri

Gambar 2 menunjukkan sebanyak 12 (35\%) subyek terdapat keadaan pergeseran ke kiri, sedangkan 22 (65\%) subyek tidak terdapat gambaran pergeseran ke kiri dari hitung jenis. 


\section{Toksik granulasi neutrofil}

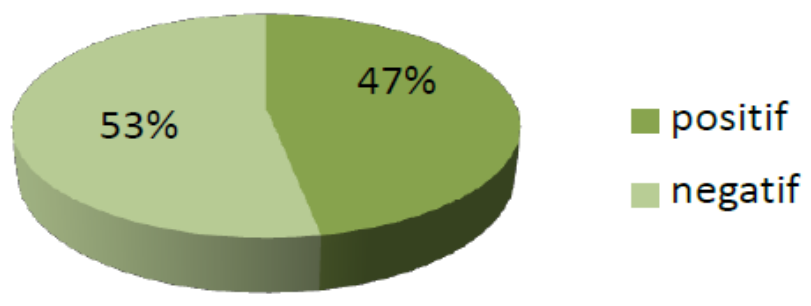

Gambar 3. Data toksik granulasi neutrofil

Gambar 3 menunjukkan sebanyak 16 (47\%) subyek terdapat keadaan granulasi toksik neutrofil, sedangkan 18 (53\%) subyek tidak terdapat gambaran granulasi toksik neutrofil dari pemeriksaan mikroskopik gambaran darah tepi.

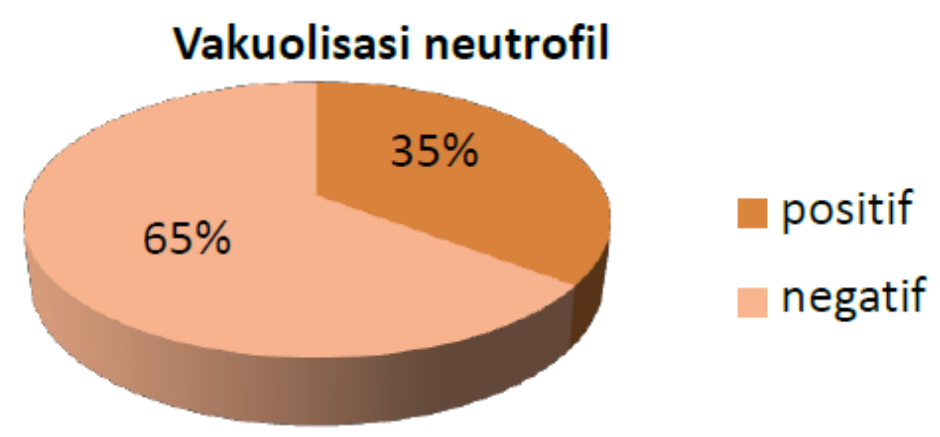

Gambar4. Data Vakuolisasi Nuetrofil

Gambar 4 menunjukkan sebanyak 12 (35\%) subyek terdapat keadaan vakuolisasi neutrofil, sedangkan $22(65 \%)$ subyek tidak terdapat keadaan neutrofil dari pemeriksaan mikroskopik gambaran darah tepi.

Uji Gamma and Somer's digunakan untuk analisis hubungan kedua variabel. Hasil uji analisis presepsin dengan gambaran pergeseran ke kiri, granulasi toksik dan vakuolisasi ditunjukkan pada tabel 1. 
Tabel 1. Hubungan presepsin dengan gambaran pergeseran ke kiri, granulasi toksik dan vakuolisasi neutrofil

\begin{tabular}{lcc}
\hline Variabel & $\mathbf{r}$ & $\boldsymbol{p}$ \\
\hline Pergeseran kekiri & 0,615 & 0,2 \\
Granulasitoksik & 0,696 & 0,001 \\
Vakuolisasi & 0,775 & 0,003 \\
Neutrofil teraktivasi (granulasi toksik dan/ & 0,749 & 0,01 \\
vakuolisasineutrofil) & & \\
Pergeseran kekiridan/ neutrofilteraktivasi & 0,744 & 0,001 \\
\hline
\end{tabular}
$p<0,05$ menunjukkan signifikasi

Seluruh variabel pergeseran ke kiri, granulasi toksik dan vakuolisasi neutrofil menunjukkan hubungan positif kuat bermakna dengan presepsin pada pasien SIRS. Hasil uji stastistik keadaan neutrofil teraktivasi yang dapat dilihat dari adanya granulasi toksik dan/atau vakuolisasi neutrofil dengan presepsin menunjukkan hubungan positif kuat bermakna. Hasil yang sama diperoleh pada uji statistik gambaran pergeseran ke kiri dan/ atau neurofil teraktivasi.

\section{PEMBAHASAN}

Gambaran adanya granulasi toksik dan/ atau vakuolisasi neutrofil menunjukkan keadaan neutrofil teraktivasi. Vakuolisasi pada neutrofil menunjukkan adanya proses fagositosis. Neutrofil yang bertemu dengan suatu partikel asing akan membentuk suatu fagosom untuk melingkupi partikel asing tersebut. ${ }^{10,14,15}$ Ditemukannya granulasi toksik menunjukkan peningkatan fungsi granula dalam neutrofil untuk menghasilkan enzim. Granula azurofilik pada neutrofil berperan untuk membunuh bakteri dan fungi.

Peningkatan jumlah neutrofil imatur (batang, metamielosit dan mielosit) pada gambaran darah tepi menunjukkan penggunaan neutrofil sebagai sel fagosit utama untuk mengatasi infeksi dari mikroba. Hasil uji statistik menunjukkan adanya hubungan positif kuat pada ketiga variabel. Hal ini menunjukkan bahwa adanya gambaran pergeseran ke kiri, granulasi toksik dan vakuolisasi neutrofil 
dapat menunjukkan keadaan sepsis yang ditunjukkan dari kadar presepsin yang lebih tinggi dari normal. ${ }^{16,17}$

Neutrofil teraktivasi dan gambaran pergeseran ke kiri dapat disebabkan adanya toksin bakteri. Fraksi soluble dari CD14 (sCD14) akan diproduksi berkaitan dengan adanya bagian dari bakteri, sehingg adapat meningkatkan kadar presepsin. Hal ini dapat menjelaskan hubungan yang kuat antara presepsin dengan ketiga variabel tersebut.

\section{SIMPULAN}

Terdapat hubungan positif kuat bermakna pada gambaran pergeseran ke kiri, granulasi toksik dan vakuolisasi neutrofil dengan kadar presepsin.

\section{SARAN}

Perlu penelitian lebih lanjut yang memeriksa kadar presepsin dan gambaran darah secara serial.

\section{DAFTAR PUSTAKA}

1. S Todi SC, S Sahu, M Bhattacharyya. Epidemiology of severe sepsis in India: an update. Crit Care. 2010;14(1):P382

2. Vincent JL, Rello J, Marshall J, Silva E, Anzueto A, Martin CD, et al. International study of the prevalence and outcomes of infection in Intensive Care Units. JAMA. 2009;302(21):2323-9

3. Meeran H, Messent $M$. The systemic inflammatory response syndrome. Trauma 2001;3:89-100

4. Siqueira-Batista R, Gomes AP, Calixto-Lima L, Vitorino RR, Perez MCA, Mendonça EG et al. Sepsis: an update. Rev Bras Ter Intensiva. 2011; 23(2):207-16

5. Darmawan I. Update on Sepsis. Ed.1. Jakarta:Farmedia;2003.hal.84-92

6. Eales LJ. Immunology for life scientist. 2nd ed. England: John Wiley \& Sons Ltd, 2003:86-103

7. Nishida T, Ishikura H, Murai A, Irie Y, Umemura T, et al. Assessment of the usefulness of presepsin (soluble CD14 subtype) in septic patients. Crit Care. 2011;15(Suppl 3):P19

8. Yaegashi Y SK, Sato N, Suzuki Y, Kojika M,ImaiS, et al. Evaluation of a newly identified soluble CD14 subtype as a marker for sepsis. J Infect Chemother. 2005;11:234-8.

9. Okamura Y, Yokoi H. Development of a point-of-care assay system for measurement of presepsin (sCD14-ST). Clin Chim Acta 2011; 412:2157-61

10.Biss Tina T, Wallace-Jonathan J. Hematological and coagulation changes in sepsis. Available from URL http://www.springerlink.com/content/j75gq6k8q87m5536/fulltext.pdf. p.1-7 
11.Layla A, Al-Gwaiz, Babay H.H. The diagnostic value of absolute neutrophil count, band count and morphologic changes of neutrophils in predicting bacterial infections. Med Princ Pract 2007; 16:344-7

12.Mitsubishi chemical medience corporation. New sepsis marker : Pathfastpresepsin. Tokyo: Mitsubishi Chemical Medience Corporation. Available at URL : http://www.medi-lab.hu/doc/Pathfast_Presepsin.pdf

13.Mitsubishi chemical medience corporation. PathfastPresepsin (reagent for Pathfast). Tokyo: Mitsubishi Chemical Medience Corporation. 2011. Available at URL : http://www.synttergy.ro/wpcontent/uploads/2011/07/Prezentare-marker-sepsis.pdf

14.Blomkalns A.L. Sick or Not Sick? : Evolving Biomarkers for Severe Bacterial Infection. EmcReg International 2007;7: 1-12

15.Bates I, BJ Brain . Approach to the diagnosis and classification of blood disease. In: SM Lewis, BJ.Brain; I.Bates, editors. Dacie and Lewis Practicalhaematology. 10th Ed. London : Elsevier:p. 609-24

16.William C.A. The hematologic system as a marker of organ dysfunction insepsis. Mayo Clin Proc 2003;78:869-8173.

17.Heper Y, Akalın E.H, Mistık R, Akgöz S, Töre O, Göral G, et all. Evaluation of serum C-reactive protein, procalcitonin, tumor necrosis factor alpha, and interleukin-10 levels as diagnostic and prognostic parameters in patients with community acquired sepsis, severe sepsis, and septic shock. Eur J Clin Microbiol Infect Dis 2006; 25:481-91 